\title{
First exposure ages from the Amundsen Sea Embayment, West Antarctica: The Late Quaternary context for recent thinning of Pine Island, Smith, and Pope Glaciers
}

\author{
Joanne S. Johnson \\ British Antarctic Survey, High Cross, Madingley Road, Cambridge CB3 OET, UK \\ Michael J. Bentley \\ Department of Geography, Durham University, South Road, Durham DH1 3LE, UK and \\ British Antarctic Survey, High Cross, Madingley Road, Cambridge CB3 OET, UK \\ Karsten Gohl \\ Alfred-Wegener-Institut für Polar- und Meeresforschung, Postfach 120161, D-27515 Bremerhaven, Germany
}

\begin{abstract}
Dramatic changes (acceleration, thinning, and grounding-line retreat of major ice streams) in the Amundsen Sea sector of the West Antarctic Ice Sheet (WAIS) have been observed during the past two decades, but the millennial-scale context for these changes is not yet known. We present the first surface exposure ages recording thinning of Pine Island, Smith, and Pope Glaciers, which all drain into the Amundsen Sea. From these we infer progressive thinning of Pine Island Glacier at an average rate of $3.8 \pm 0.3 \mathrm{~cm} \mathrm{yr^{-1 }}$ for at least the past $4.7 \mathrm{k.y}$. , and of Smith and Pope Glaciers at $2.3 \pm 0.2 \mathrm{~cm} \mathrm{yr}^{-1}$ over the past $14.5 \mathrm{k.y}$. These rates are more than an order of magnitude lower than the $\sim 1.6 \mathrm{~m} \mathrm{yr}^{-1}$ recorded by satellite altimetry for Pine

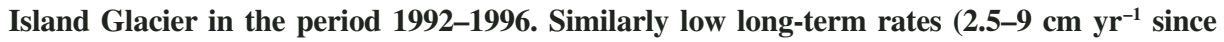
$10 \mathrm{ka}$ ) have been reported farther west in the Ford Ranges, Marie Byrd Land, but in that area, the same rates of thinning continue to the present day. Our data provide the first evidence that puts into context recent rates of thinning of the WAIS in the Amundsen Sea Embayment and demonstrates that these are unusually rapid. The data also provide much-needed constraints for ice sheet models, which are the primary tool for predicting the future behavior of the WAIS and its likely contribution to sea-level rise.
\end{abstract}

Keywords: West Antarctic Ice Sheet, Pine Island Glacier, exposure age, cosmogenic isotopes, glacial history.

\section{INTRODUCTION AND BACKGROUND}

This paper presents the first surface exposure ages recording the long-term thinning history of Pine Island Glacier (PIG) and the surrounding area. This region is critically important because changes are happening faster here than anywhere else in the West Antarctic Ice Sheet (WAIS). In addition, this sector has long been identified as the "weak underbelly" of the WAIS (Hughes, 1981), and has the potential to raise sea level by as much as $\sim 1 \mathrm{~m}$ (Holt et al., 2006; Vaughan et al., 2006). In the past two decades, three adjacent glaciers (Pine Island, Thwaites, and Smith; Fig. 1), in dynamically independent glacial basins draining into the Amundsen Sea, have significantly accelerated (e.g., Rignot et al., 2002) and thinned (Shepherd et al., 2004), possibly in response to ocean warming (Payne et al., 2004). The greatest acceleration ( $>25 \%$ between 1974 and 2003) has been observed for PIG (Joughin et al., 2003). Glaciologists are currently trying to assess the cause of the dramatic changes in the Amundsen Sea sector and their implications for the future behavior of the WAIS.
The Holocene context for the recent change in PIG is, however, not yet well known due to a lack of data from the region. The only study that gives deglaciation ages from Pine Island Bay thus far (Lowe and Anderson, 2002) used a combination of marine geomorphological evidence and a small number of radiocarbon dates to infer that PIG was grounded on the outer shelf at its maximum extent, and retreated to within $200 \mathrm{~km}$ of the present-day grounding line by $10.2 \pm 0.4{ }^{14} \mathrm{C}$ ka (uncorrected). Outside our study area, and much farther west, Stone et al. (2003) used exposure ages from the Ford Ranges to demonstrate that thinning of the WAIS has been ongoing since the early Holocene and continues at a similar rate today (Davis et al., 2005). Nevertheless, we cannot yet build a coherent picture of Holocene retreat in the Amundsen Sea Embayment as a whole, nor for individual glaciers, because data are temporally and spatially inadequate.

Understanding the long-term (millennial) history of the Amundsen Sea Embayment of the WAIS is essential for assessing the significance of recent (annual to decadal) changes, and also for constraining ice sheet models. Because it is well known that individual glacier drainage basins in Antarctica can respond in differing ways to external forcing (see review in Sugden et al., 2006), it is crucial that ice sheet models should demonstrate skill in simulating past ice sheet behavior before they can be relied upon for prediction (Vaughan and Arthern, 2007). Data showing the extent and thickness of the WAIS in the Amundsen Sea sector are thus essential for reliable prediction of future ice sheet stability and sea-level change. This paper presents surface exposure ages that constrain the Holocene behavior of ice in the Amundsen Sea Embayment.

\section{STUDY AREA AND METHODS}

We collected samples from four sites surrounding Pine Island Bay (Fig. 1), using helicopter support during RV Polarstern cruise ANT-XXIII/4 (Larter et al., 2007). These sites were Hunt Bluff (HB), Turtle Rock (TR), Mount Manthe (MM), and an unnamed island (ISL) in the Lindsey Islands group, Pine Island Bay. The wide spatial distribution of these 


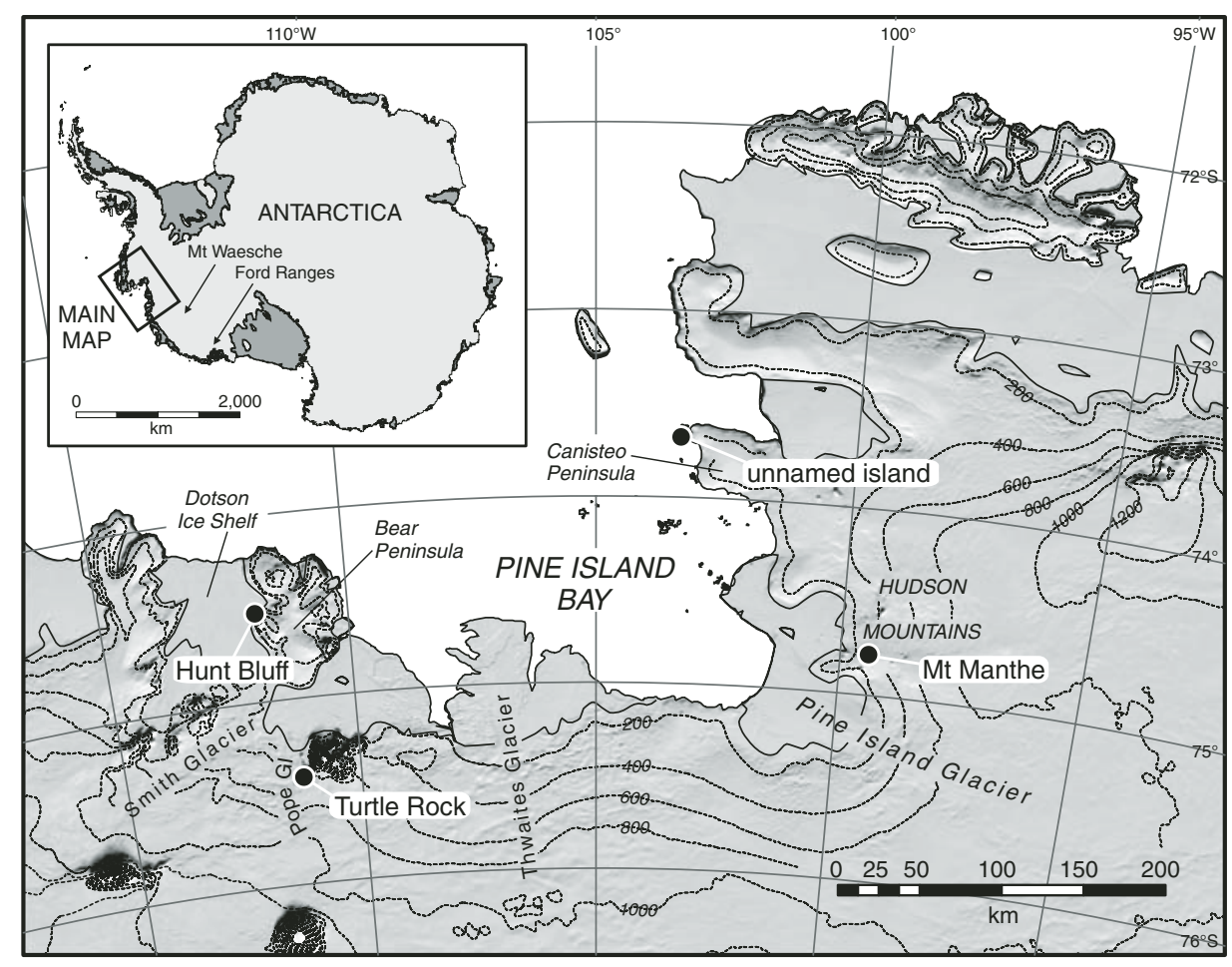

Figure 1. Map of Pine Island Bay sector showing the sampling sites for surface exposure dating. Gray-scale image onshore is part of the MODIS (moderate-resolution imaging spectroradiometer) Mosaic of Antarctica (National Aeronautics and Space Administration Goddard Space Flight Center). Contours are at $\mathbf{2 0 0} \mathrm{m}$ intervals.

samples was dictated by helicopter range and ship position in this remote area, but they provide the first onshore chronological constraints for this part of the WAIS.

Nunataks that rise above the present-day ice sheet can be used as dipsticks for past ice thickness, since glacial geomorphological evidence on them (such as erratic boulders, striated bedrock, and till) reflects former ice cover and can be dated to determine the timing of ice retreat. To this end, we collected erratic boulders from sites on the margin (MM) and downstream (ISL) of Pine Island Glacier, and from the margin of Pope and Smith Glaciers (TR). In addition, we sampled bedrock downstream of Smith Glacier (HB). The nunataks rise above the present-day ice sheet by $\sim 275-400 \mathrm{~m}$.

Glacial deposits at TR and MM consist of a variety of granitic boulders and cobbles scattered on underlying basaltic lava/hyaloclastite bedrock or embedded within till (Figs. $2 \mathrm{~A}-2 \mathrm{C}$ ). The highest erratic found was $12 \mathrm{~m}$ below the summit of TR, at $700 \mathrm{~m}$ above sea level (a.s.1.). Hunt Bluff is at $470 \mathrm{~m}$ a.s.l. on the western side of Bear Peninsula, adjacent to the Dotson Ice Shelf (Fig. 1). Here erratics are rare and consist of only a few exotic glacially transported cobbles perched on the granite bedrock. This is the only location where striations were found (Fig. 2D). Striations indicate that erosive ice passed over the bluff, but since the ice retreated, erosion has been negligible. As well as these nunatak sites, we obtained a sample from a low-lying $(<15 \mathrm{~m}$ a.s.1.), ice-free island (ISL) $\sim 1.5 \mathrm{~km}$ west of the present-day ice margin of Canisteo Peninsula (Fig. 2E). The island is unusual in that it is the only one in the vicinity that is ice free, and the only one that is occupied (presumably seasonally) by elephant seals and Adélie penguins. ISL is mantled with fine-grained sediment in which erratics are embedded. We sampled a 1-m-high boulder (Fig. 2F).

We determined cosmogenic surface exposure ages on these samples using the abundance of ${ }^{10} \mathrm{Be}$ and ${ }^{26} \mathrm{Al}$ within pure quartz grains that were separated from each rock sample (details of the samples, chemical procedures, age calculation, and the isotopic data are given in GSA Data Repository Appendix DR1 and Tables DR $\left.1-D R 3^{1}\right)$. We obtained ${ }^{10} \mathrm{Be}$ exposure ages from erratic boulders at TR, MM, and ISL, and paired ${ }^{10} \mathrm{Be}-{ }^{26} \mathrm{Al}$ ages from bedrock at $\mathrm{HB}$.

'GSA Data Repository item 2008056, Appendix DR1 (description of surface exposure dating method), Figure DR1 (two-isotope diagram), and Tables DR1-DR3 (sample information, accelerator mass spectroscopy measurements, and exposure ages), is available online at www.geosociety.org/pubs/ft2008. htm, or on request from editing@geosociety.org or Documents Secretary, GSA, P.O. Box 9140, Boulder, CO 80301, USA

\section{RESULTS AND DISCUSSION}

We obtained seven ${ }^{10} \mathrm{Be}$ and one ${ }^{26} \mathrm{Al}$ exposure ages. Six of the ${ }^{10} \mathrm{Be}$ ages, all on erratics, postdate the Last Glacial Maximum (LGM). At TR, two of the samples (with ages of $14.5 \pm 1.2$ and $11.7 \pm 1.2 \mathrm{ka}$ ) record a general progression of decreasing age with decreasing elevation (Fig. 3A). A third boulder yielded an age of $19.8 \pm$ $1.6 \mathrm{ka}$. This is significantly older than another sample at a similar altitude. At MM (Fig. 3B), there is a comparable relationship between the ages of two samples $(8.3 \pm 0.7$ and $4.7 \pm$ $0.3 \mathrm{ka}$ ), also at similar altitudes. An erratic from ISL yielded an age of $2.2 \pm 0.2 \mathrm{ka}$ close to sea level (Fig. 3C). A seventh ${ }^{10} \mathrm{Be}$ age (113.2 \pm $7.4 \mathrm{ka}$ ) comes from bedrock at $\mathrm{HB}$, where we also obtained a paired ${ }^{26} \mathrm{Al}$ age $(106.2 \pm 7.2 \mathrm{ka})$.

Figure 3 shows the age-elevation relationships and present-day ice surface elevations. The elevations of our samples indicate that the ice sheet must formerly have been at least $334 \mathrm{~m}$ and $191 \mathrm{~m}$ thicker than present at TR and MM, respectively. Our highest sample from TR was collected close to the summit; this location, combined with its postglacial age (14.5 \pm $1.2 \mathrm{ka}$ ), implies that no part of this nunatak was above the surface of the ice sheet at the LGM. The upper part of MM $(>550 \mathrm{~m})$ is currently covered by ice, so we have no samples from higher than $480 \mathrm{~m}$. Thus, using these data, we are unable to constrain the date of the LGM in this region or its maximum ice thickness. However, the exposure ages provide valuable constraints on the thinning history of adjacent glaciers. At TR and MM, the samples appear to record a decline in ice elevation with time. However, at both sites, there are samples at similar altitudes with significantly different ages. We follow the reasoning of Bentley et al. (2006) that in these cases the youngest sample is the best estimate of the true exposure age for deglaciation. At TR, the oldest sample was embedded in till. We suggest that it was most likely deposited by an earlier ice advance, and retains some inherited ${ }^{10} \mathrm{Be}$ from a previous period of exposure. At MM, we cannot exclude an ice sheet history where the ice was only $10 \mathrm{~m}$ thicker at $8.3 \mathrm{ka}$ than it was at $4.7 \mathrm{ka}$. Alternatively, given the data at TR, it is possible that the age of the older MM sample reflects inheritance. The age-elevation relationships allow us to estimate long-term average thinning rates (these are minimum rates since we cannot rule out the possibility that our youngest samples have undergone prior exposure). We obtained rates of $2.3 \pm 0.2 \mathrm{~cm} \mathrm{yr}^{-1}$ over the past $14.5 \mathrm{k} . \mathrm{y}$. for Smith and Pope Glaciers at TR (Fig. 3A), and $3.8 \pm 0.3 \mathrm{~cm} \mathrm{yr}^{-1}$ over the past $4.7 \mathrm{k} . \mathrm{y}$. for Pine Island Glacier at MM (Fig. 3B). The thinning rate determined from the youngest two samples at TR projects to the present ice surface (Fig. 3A), giving the strongest evidence 


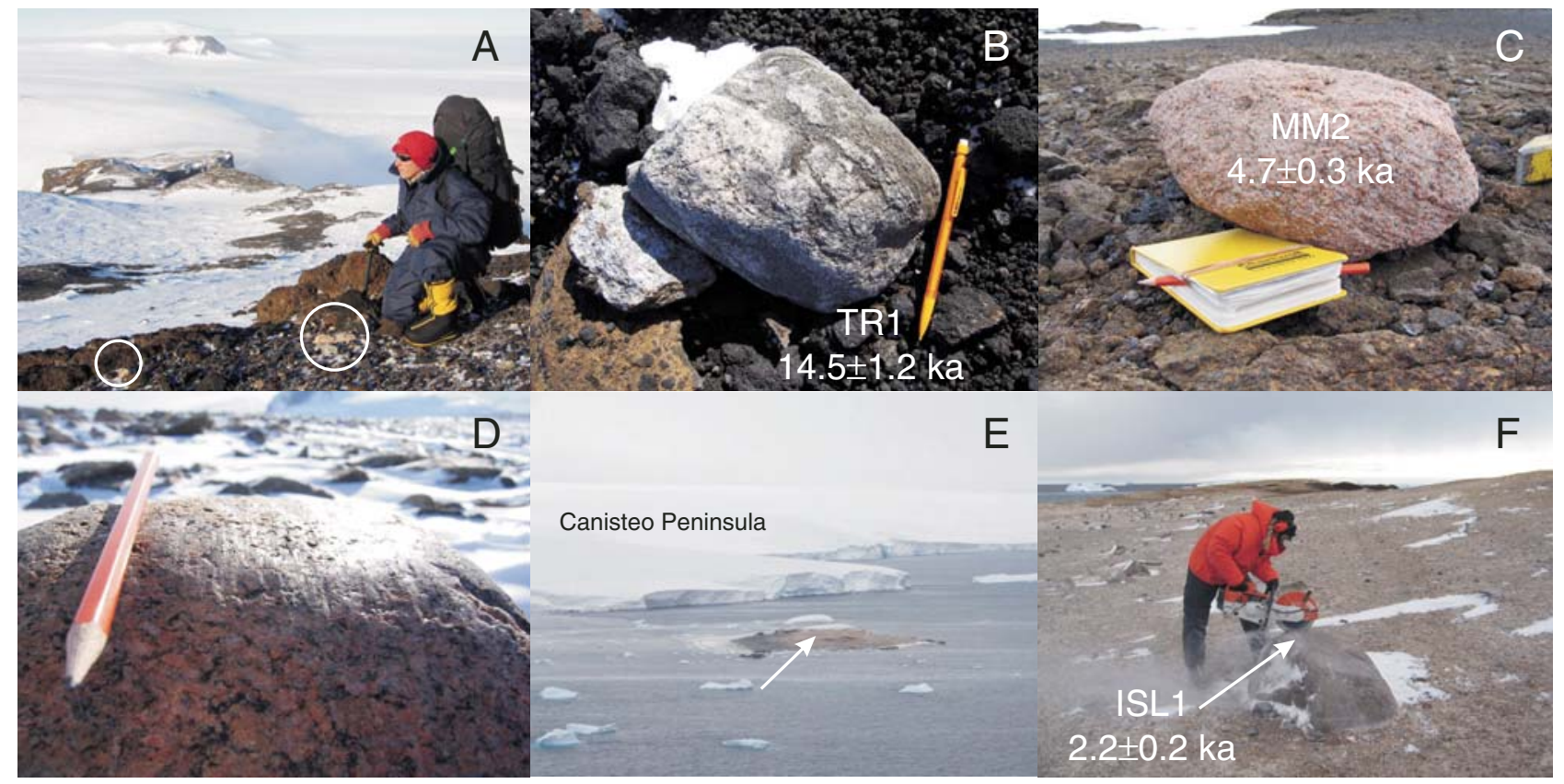

Figure 2. A: View from Turtle Rock looking south toward Dorrel Rock and Mount Takahe. Till containing granite erratics (circled) is visible in foreground. B: Gneissic erratic TR1 near summit of Turtle Rock. C: Isolated granite erratic MM2 at Mount Manthe. D: Striations on granite bedrock at Hunt Bluff. E: View of ice-free unnamed island. Arrow points to sample location. Present-day ice margin on Canisteo Peninsula is in the background. F: Erratic boulder ISL1 on the unnamed island.

from our four sample sites for gradual thinning of the WAIS during the Holocene.

The ${ }^{10} \mathrm{Be}$ exposure age of $2.2 \pm 0.2 \mathrm{ka}$ from ISL could be interpreted as recording one of two events: (1) the time when the island was first exposed by retreat of the ice front, or (2) emergence of the island from the sea due to isostatic rebound after deglaciation. Our late Holocene exposure age is consistent with our evidence for progressive Holocene thinning of the PIG upstream of this site at MM. However, the proximity of the island to Canisteo Peninsula (Fig. 2E) means that we cannot rule out the possibility that exposure of the island is related to retreat of the "local" ice front. The alternative hypothesis of glacio-isostatic rebound can be assessed using relative sea-level predictions from a coupled solid earth-ice sheet model. We examined sea-level predictions for the island using the range of deglaciation scenarios in Bassett et al. (2007). The elevation (8 m a.s.1.) of the sample is only consistent with deglaciation scenarios requiring the loss of relatively large ice volumes (G. Milne, 2007, personal commun.), which are at the upper limit of what is thought geologically feasible across Antarctica (see review in Bassett et al., 2007). Therefore, while the exposure age may represent the timing of isostatic emergence, we believe it is more likely that it reflects recent retreat of the nearby ice front. However, even if it reflects emergence, the date still provides a minimum constraint on the timing of ice sheet retreat. The close proximity of the ice front to the island
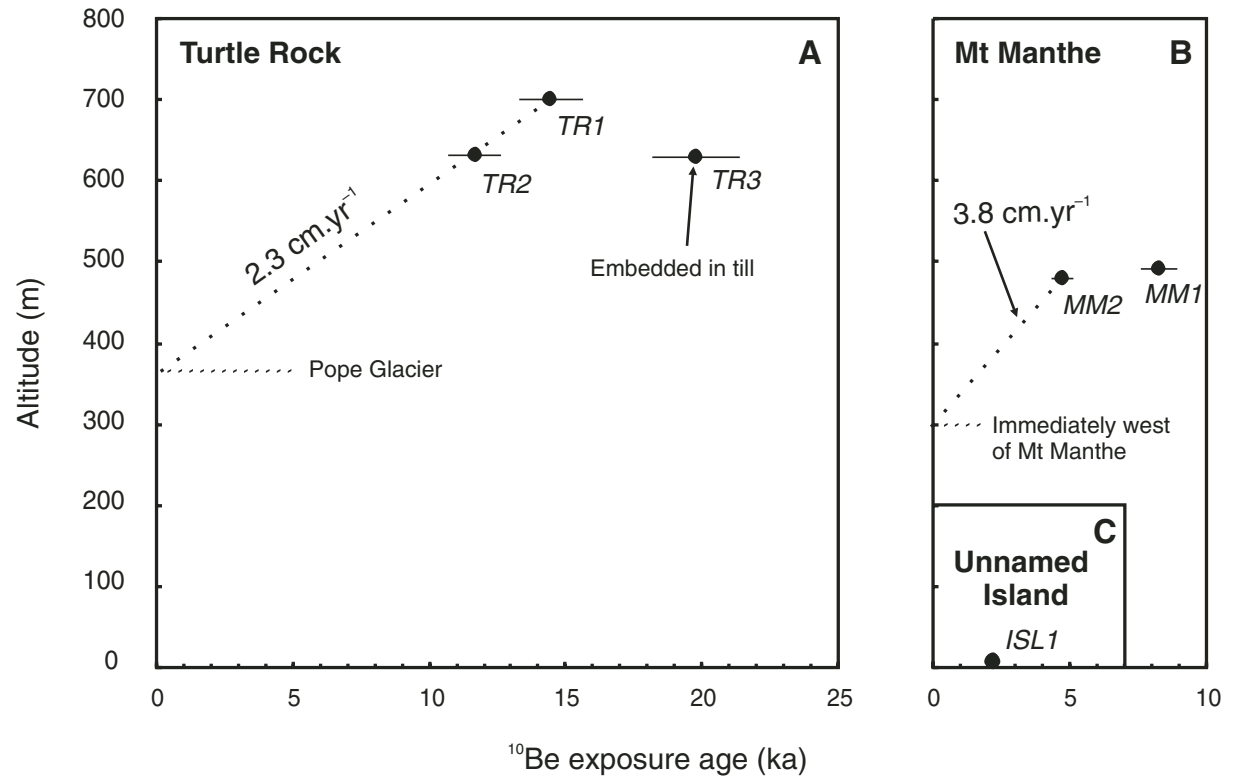

Figure $3 .{ }^{10} \mathrm{Be}$ exposure age versus elevation for samples. A: Turtle Rock (TR). B: Mount Manthe (MM). C: Unnamed island (ISL) near Canisteo Peninsula. Short-dashed lines are present-day ice elevations, and dotted lines are average ice thinning rates. Error bars are $1 \sigma$.

$(\sim 1.5 \mathrm{~km})$ suggests that the ice front has been stable for the past $2.2 \mathrm{k} . \mathrm{y}$., or that it may have advanced from a more restricted position.

The paired ${ }^{10} \mathrm{Be}-{ }^{26} \mathrm{Al}$ data at $\mathrm{HB}$ plot below the lower boundary of the "erosion island" on a two-isotope diagram (Fig. DR1; see footnote 1). Because HB is striated, we can assume that erosion has been negligible, but the ${ }^{26} \mathrm{Al} /{ }^{10} \mathrm{Be}$ ratio of HB1 suggests that the sample underwent at least one period of shielding and/or burial (Bierman et al., 1999). For this reason, we do not use this sample further to constrain the post-LGM history.

In summary, our data set shows progressive thinning of the WAIS in the Amundsen Sea Embayment since $14.5 \mathrm{ka}$, and allows estima- 
tion of long-term thinning rates. However, we are unable to constrain the timing of the LGM or maximum thickness of the LGM ice sheet. We believe that the late Holocene exposure age for the unnamed island is most likely to reflect local ice retreat, rather than emergence due to isostatic rebound.

Our data show that deglaciation of TR was underway by $14.5 \pm 1.2 \mathrm{ka}$ (Fig. 3A). This is slightly earlier than the onset of deglaciation in western Marie Byrd Land (ice began to retreat from Mount Waesche ca. 10 ka [Ackert et al., 1999]; and the now-exposed rock of the Ford Ranges deglaciated within the past $10.4 \pm$ 0.7 k.y. [Stone et al., 2003]). Our estimated thinning rates for TR and MM (2.3-3.8 $\left.\mathrm{cm} \mathrm{yr}^{-1}\right)$ are consistent with Holocene thinning rates observed elsewhere in Marie Byrd Land: 2.5$9 \mathrm{~cm} \mathrm{yr}^{-1}$ in the Ford Ranges (Stone et al., 2003; Sugden et al., 2005). However, they are more than an order of magnitude lower than those observed for PIG between 1992 and 1996: satellite altimetry detected that the grounded part of PIG had thinned by as much as $1.6 \mathrm{~m} \mathrm{yr}^{-1}$ (Shepherd et al., 2001). Our new data put these recent more rapid rates of the WAIS thinning in the Amundsen Sea Embayment into a longerterm context: for at least the past 14.5 k.y., glaciers there have been thinning at an average rate of a few centimeters per year. Recent thinning rates of about one meter per year cannot have been sustained for the whole of the Holocene, although short-lived periods of such rapid thinning may have occurred (we do not yet have the abundance of data or resolution required to distinguish such events in this region).

Compared with the limited marine data available for Pine Island Bay, the thinning history recorded by our samples is consistent with the overall retreat pattern described by Lowe and Anderson (2002) of retreat of ice from the outer continental shelf prior to $15.8 \pm 3.9{ }^{14} \mathrm{C} \mathrm{ka}$ (uncorrected), passing within $200 \mathrm{~km}$ of the present-day grounding line by $10.2 \pm 0.3{ }^{14} \mathrm{C} \mathrm{ka}$ (uncorrected). Our evidence for progressive thinning implies that retreat following $10.2 \mathrm{ka}$ has been relatively gradual, and reached close to Canisteo Peninsula by $2.2 \mathrm{ka}$.

\section{CONCLUSIONS}

We have obtained the first surface exposure ages from the Pine Island region, which provide constraints on the postglacial thinning history of this part of the WAIS. These ages record progressive thinning of Pine Island Glacier for at least the past 4.7 k.y., and of Smith and Pope Glaciers for the past 14.5 k.y.. The longterm average thinning rates for the glaciers are between $3.8 \pm 0.3$ and $2.3 \pm 0.2 \mathrm{~cm} \mathrm{yr}^{-1}$. These rates are more than an order of magnitude lower than recent satellite-derived thinning rates for Pine Island Glacier of as much as $1.6 \mathrm{~m} \mathrm{yr}^{-1}$, supporting the idea that the recently observed behavior cannot have been sustained over more than a few decades.

We are as yet unable to constrain the date of the Last Glacial Maximum in this region, or the maximum thickness of the WAIS at that time. To do so would require sampling nunataks with a greater relief above the present ice surface.

We obtained an exposure age of $2.2 \pm 0.2 \mathrm{ka}$ for an island in Pine Island Bay. Exposure of the island was most likely to be the result of retreat of the ice sheet to its present position on Canisteo Peninsula. However, we cannot rule out the possibility that this date reflects glacioisostatic emergence, in which case it gives a minimum age for ice sheet retreat.

\section{ACKNOWLEDGMENTS}

We thank the Captain and crew of RV Polarstern, the pilots of HeliTransair and Terry O'Donovan (field assistant) for supporting Johnson in Antarctica, and Tibor Dunai for allowing her to use the Edinburgh University cosmogenic isotope facility. We also thank Steve Binnie, Hilary Blagbrough, Stewart Freeman, Elaine McDougall, Christoph Schnabel, and Mike Tabecki for their technical support, and Greg Balco, Chris Fogwill, Claus-Dieter Hillenbrand, Rob Larter, John Smellie, and David Vaughan for helpful discussions. Peter Fretwell drafted Figure 1. This work contributes to the British Antarctic Survey GRADES (Glacial Retreat in Antarctica and Deglaciation of the Earth System) programme. We thank Robert Ackert and John Anderson for useful reviews.

\section{REFERENCES CITED}

Ackert, R.P., Jr., Barclay, D.J., Borns, H.W., Calkin, P.E., Kurz, M.D., Fastook, J.L., and Steig, E.J., 1999, Measurements of past ice sheet elevations in interior West Antarctica: Science, v. 286, p. 276-280, doi: 10.1126/science.286.5438.276.

Bassett, S.E., Milne, G.A., Bentley, M.J., and Huybrechts, P., 2007, Modelling Antarctic sealevel data to explore the possibility of a dominant Antarctic contribution to meltwater pulse IA: Quaternary Science Reviews, v. 26, p. 21132127, doi: 10.1016/j.quascirev.2007.06.011.

Bentley, M.J., Fogwill, C.J., Kubik, P.W., and Sugden, D.E., 2006, Geomorphological evidence and cosmogenic ${ }^{10} \mathrm{Be} /{ }^{26} \mathrm{Al}$ exposure ages for the Last Glacial Maximum and deglaciation of the Antarctic Peninsula Ice Sheet: Geological Society of America Bulletin, v. 118, p. 1149-1159, doi: 10.1130/B25735.1.

Bierman, P.R., Marsella, K.A., Patterson, C., Davis, P.T., and Caffee, M., 1999, Mid-Pleistocene cosmogenic minimum-age limits for preWisconsinan glacial surfaces in southwestern Minnesota and southern Baffin Island: A multiple nuclide approach: Geomorphology, v. 27, p. 25-39, doi: 10.1016/S0169$555 \mathrm{X}(98) 00088-9$.

Davis, C.H., Yonghong, L., McConnell, J.R., Frey, M.M., and Hanna, E., 2005, Snowfall-driven growth in East Antarctic Ice Sheet mitigates recent sea-level rise: Science, v. 308, p. 1898-1901, doi: 10.1126/science.1110662.

Holt, J.W., Blankenship, D.D., Morse, D.L., Young, D.A., Peters, M.E., Kempf, S.D., Richter, T.G., Vaughan, D.G., and Corr, H.F.J., 2006, New boundary conditions for the West Antarctic Ice Sheet: Subglacial topography of the Thwaites and Smith glacier catchments: Geo- physical Research Letters, v. 33, L09502, doi: 10.1029/2005GL025561.

Hughes, T.J., 1981, The weak underbelly of the West Antarctic ice sheet: Journal of Glaciology, v. 27 , p. $518-525$

Joughin, I., Rignot, E., Rosanova, C.E., Lucchitta, B.K., and Bohlander, J., 2003, Timing of recent accelerations of Pine Island Glacier, Antarctica: Geophysical Research Letters, v. 30, p. 1706, doi: 10.1029/2003GL017609.

Larter, R.D., Gohl, K., Hillenbrand, C.-D., Kuhn, G., Deen, T.J., Dietrich, R., Eagles, G., Johnson, J.S., Livermore, R.A., Nitsche, F.O., Pudsey, C.J., Schenke, H.-W., Smith, J.A., Udintsev, G., and Uenzelmann-Neben, G., 2007, West Antarctic Ice Sheet change since the last glacial period: Eos (Transactions, American Geophysical Union), v. 88, p. 189-196, doi: 10.1029/2007EO170001

Lowe, A.L., and Anderson, J.B., 2002, Reconstruction of the West Antarctic ice sheet in Pine Island Bay during the Last Glacial Maximum and its subsequent retreat history: Quaternary Science Reviews, v. 21, p. 1879-1897, doi: 10.1016/S0277-3791(02)00006-9.

Payne, A.J., Vieli, A., Shepherd, A.P., Wingham, D.J., and Rignot, E., 2004, Recent dramatic thinning of largest West Antarctic Ice Stream triggered by oceans: Geophysical Research Letters, v. 31, L23401, doi: 10.1029/2004GL021284.

Rignot, E., Vaughan, D.G., Schmeltz, M., Dupont, T., and MacAyeal, D., 2002, Acceleration of Pine Island and Thwaites Glaciers, West Antarctica: Annals of Glaciology, v. 34, p. 189-194.

Shepherd, A., Wingham, D.J., Mansley, J.A.D., and Corr, H.F.J., 2001, Inland thinning of Pine Island Glacier: Antarctic Science, v. 291, p. 862-864.

Shepherd, A., Wingham, D., and Rignot, E., 2004, Warm ocean is eroding West Antarctic Ice Sheet: Geophysical Research Letters, v. 31, L23402, doi: 10.1029/2004GL021106.

Stone, J.O., Balco, G.A., Sugden, D.E., Caffee, M.C., Sass, L.C., III, Cowdery, S.G., and Siddoway, C., 2003, Holocene deglaciation of Marie Byrd Land: West Antarctica: Science, v. 299, p. 99-102, doi: 10.1126/science.1077998.

Sugden, D.E., Balco, G., Cowdery, S.G., Stone, J.O., and Sass, L.C., III, 2005, Selective glacial erosion and weathering zones in the coastal mountains of Marie Byrd Land, Antarctica: Geomorphology, v. 67, p. 317-334, doi: 10.1016/ j.geomorph.2004.10.007.

Sugden, D.E., Bentley, M.J., and Ó Cofaigh, C., 2006 , Geological and geomorphological insights into Antarctic ice sheet evolution: Royal Society of London Philosophical Transactions, ser. A, v. 264 , p. $1607-1625$.

Vaughan, D.G., and Arthern, R., 2007, Climate change: Why is it hard to predict the future of ice sheets?: Science, v. 315, p. 1503-1504, doi: 10.1126/science.1141111.

Vaughan, D.G., Corr, H.J.F., Ferraccioli, F., Frearson, N., O'Hare, A., Mach, D., Holt, J.W., Blankenship, D.D., Morse, D.L., and Young, D.A., 2006, New boundary conditions for the West Antarctic ice sheet: Subglacial topography beneath Pine Island Glacier: Geophysical Research Letters, v. 33, L09501, doi: 10.1029/2005GL025588.

Manuscript received 22 June 2007

Revised manuscript received 15 November 2007 Manuscript accepted 25 November 2007

Printed in USA 